\title{
15
}

\section{Micronesian Sub-Regional Diplomacy}

\section{Suzanne Lowe Gallen}

Shifts in Pacific diplomacy, governance and development priorities are changing the context of Pacific regionalism. In these shifts, Melanesian countries are represented by the Melanesian Spearhead Group (MSG) and Polynesian countries have formed their own sub-regional response via the Polynesian Leaders Group (PLG). But what of the Micronesian sub-region? Little is known of the North Pacific's sub-regional experience, let alone its history, cultural context and governance structures. This chapter will highlight some of those experiences by pointing out the similarities and differences between the two main Micronesian sub-regional entities: the Micronesian Presidents Summit (MPS) and the Micronesian Chief Executives Summit (MCES), as well as some of the failures and successes of Micronesian sub-regionalism.

There are several prevailing misconceptions, and perhaps misrepresentations, of the north Oceanic sub-region. It is perhaps a misnomer to use the term 'North Pacific' when referring to Micronesia because Kiribati and Nauru are geographically south - the equator being the obvious divider. The terminology may sometimes also be complicated by geographic references in the United States - the 'North Pacific' or 'Pacific Northwest' refer to the US states of Washington, Oregon, and British Columbia. It is sometimes important to make this distinction because of the close Micronesian affiliations with the US. The confusion may not be so much of an issue in the South Pacific, where 
the US North Pacific probably is hardly ever, if at all, a topic of discussion or reference. It is undoubtedly more geographically and politically correct to refer to the sub-region as 'Northern and Central Oceania' or simply the 'Central Pacific.' Another identifying term that is used for the three northern Micronesian sovereign states is the 'Freely Associated States' (FAS), which is an entirely neo-colonial term in the sense that its primary reference is to the subregion's relationship with the US. Another term commonly used in Micronesia for the three sovereign FAS is 'US-affiliated states', while the extension 'and territories' refers to the inclusion of the US territories of Guam and the Commonwealth of the Northern Mariana Islands (CNMI), as well as one nonMicronesian US territory - American Samoa - which is in Polynesia. Neither of these geopolitical identifiers includes the two Micronesian states south of the equator - Kiribati and Nauru — which are not US-affiliated and have more ties to Australia and other British Commonwealth countries, as former colonies of Great Britain. The focus of this chapter is the northern Pacific or northern Micronesia, terms that will be used interchangeably and are meant to describe Micronesian states north of the equator, more specifically, the Republic of the Marshall Islands (RMI), the Federated States of Micronesia (FSM) and the Republic of Palau, but also the US territories of Guam and the CNMI.

There are two main sub-regional bodies in northern Oceania. The MPS is an annual meeting among the three sovereign countries - FSM, RMI, and Palau. The MCES is a similar body, but also includes Guam and the CNMI, as well as the four states of the FSM (Pohnpei, Chuuk, Kosrae, and Yap). The issues discussed at each conference are often very similar, sometimes even the same, but their approaches are entirely different, given that one entity comprises sovereign states, while the other also includes non-sovereign states.

\section{Political Background of Micronesia}

Micronesia is made up of over 2,000 islands, with a land area of 2,700 square kilometres and an ocean area of 7.4 million square kilometres. Historically, there are four main island groups: the Gilberts and Nauru; the Carolines (which comprises Palau, Yap, Chuuk, Pohnpei, and Kosrae); the Marianas (comprising Guam and CNMI); and the Marshall Islands. This chapter mostly discusses the latter three, or those that make up what is often referred to as the northern Pacific, as discussed above: the three sovereign states of the RMI, FSM and Palau and two territories under the US - Guam and the CNMI. As a side note, one of the three independent states, the FSM, is made up of five separate governments (the four state governments and the national government); this is why there are often references to more governments than there are countries. 
Northern Micronesia was colonised by Spain, Germany and Japan, before falling under United Nations (UN) trusteeship, administered by the US. This mandate was called the Trust Territory of the Pacific Islands (TTPI), which was initially under control of the US Navy, before being handed over to the US Department of the Interior in the early 1950s.

\section{Overview of Government Structures}

In the mid-1970s, efforts toward sovereignty finally made headway and a political futures committee was commissioned. The committee produced several political options from which the islands could choose, this is how the sub-region ended up with a variety of government structures. Guam opted to remain a US territory; CNMI opted for commonwealth status (which holds an entirely different meaning here than is referred to in the British/Australian system); the four states of Yap, Chuuk, Kosrae, ${ }^{1}$ and Pohnpei became the FSM ${ }^{2}$ and opted for a federation in free association with the US, as did RMI. Palau was the last TTPI district to become independent in 1994, also opting for free association.

The referenda of the 1970s laid out the governments that exist today in northern Micronesia. The three sovereign FAS, in keeping with the terminology introduced earlier, are all constitutional democracies in free association with the US. However, in terms of government structures, this is where the similarities end. The FSM has a highly decentralised national government with four states, each with its own separate government, and a unicameral congress from which the president and vice president are elected. The RMI operates as a mixed parliamentary-presidential government, with the president elected by the Nitijela (parliament). The Republic of Palau (ROP) has a bicameral congress called the Olbiil Era Kelulau with the president and vice president elected by popular vote.

\section{Challenges}

The challenges the sub-region faces are similar to challenges faced in other parts of the Pacific and other small island developing states: climate change, food security, high transportation costs, unreliable shipping services, geographical limitations, limited resources, and high emigration rates. There are other

\footnotetext{
1 Kosrae was initially an outer island of Pohnpei, but became a state when the FSM was formed.

2 While constitutions were adopted in 1979, US administration formally ended in RMI and FSM in 1986 with the signing of the Compacts of Free Association. The UNSC formally ended their trusteeship status in 1990, the same year they both became UN members.
} 
challenges that are more unique to certain Micronesian islands, such as an air service monopoly (in the FSM), and uncertainties regarding the future of economic provisions under Compacts of Free Association with the US.

\section{Micronesian Sub-Regionalism}

As a response to the many challenges faced by the sub-region, bilateral and multilateral cooperation through sub-regional bodies has increased in the past two decades, particularly since the late 1990s and early 2000s. It was around this time that significant changes in Pacific regionalism were also taking shape, signalling broader inclusivity. In 1997, the South Pacific Commission changed its name to the Secretariat of the Pacific Community to better reflect its wider Pacific membership (SPC 2011). Following suit, discussions at the 29th South Pacific Forum (SPF) hosted by the FSM in 1998 included the issue of changing the name of the forum to be more inclusive of northern Pacific members. The name was formally changed to the Pacific Islands Forum at the 2000 Annual Forum Meeting, hosted by Kiribati (PIFS 2015). In early 2000, the Secretariat of the Pacific Community (SPC) welcomed its first Micronesian head, Chamorro Lourdes T. Pangelinan (SPC 2011). Pangelinan served six years as SPC's head, leaving behind other legacies - being the first female head of SPC and with the opening of a North Pacific Regional Office in Pohnpei, FSM, in January 2006, the same month she left the organisation. The South Pacific Regional Environmental Programme also appointed a Micronesian, H.E. Asterio Takesy, to serve as its executive director in late 2002. Takesy served two consecutive three-year terms, from 2003 until 2009.

Despite these attempts at greater representation from the northern Pacific, and the changes in Pacific regionalism to incorporate Micronesia more explicitly in South Pacific regionalism, more often than not northern Micronesia has been sidelined in Pacific regional issues, owing largely to geographical distance (and related transportation limitations), but mostly due to historical and political dissimilarities as a result of being colonised by the US (compared to the South Pacific's affiliations with European colonisers). Up until very recently, while the South Pacific may sometimes go to great lengths to include them, northern Micronesian participation in Pacific regional matters has largely been characterised by a sense of detachment.

The relegation of Micronesia may sometimes be self-perpetuated, as in the case of the FSM Department of Foreign Affairs receiving executive instructions from President Emanuel Mori in 2007 to close down its embassy in Suva. While the FSM embassy closure never materialised, it suggested that the newly appointed FSM president was dismissing Pacific relationships as inconsequential to his 
country's priorities. This could not have been farther from the truth, particularly when it comes to issues such as climate change, which the FSM leadership would have quickly come to realise had it not been for other leaders in the northern Pacific pushing the issues through already established sub-regional entities the MPS and the MCES. ${ }^{3}$

\section{Micronesian Presidents' Summit}

In May 2001, leaders from the three northern Pacific sovereign countries, Leo A. Falcam from the FSM, Tommy Remengesau Jr from the Republic of Palau, and Kessai Note from the Republic of the Marshall Islands, met in Pohnpei to discuss issues of 'working together to improve communication and planning on areas of common interest to their nations and to the region' (FSM Information Services 2001). The meeting was called by President Falcam as a way of forging a common ground to establish closer ties, and to communicate on national and regional issues of mutual concern and importance to the three nations (FSM Information Services 2001). Of particular urgency at the time were issues of maritime surveillance and opportunities for information technology upgrades, but also high on the list of priority issues was the matter of US withdrawal from the Kyoto Protocol (FSM Information Services 2001). These and other issues discussed at the first meeting laid a foundation for future meetings.

At a second presidential meeting in 2002, recognising the fact that each of the three nations was becoming more involved in regional and international forums, it was agreed to begin negotiating with one another to establish an official North Pacific regional alliance. This official alliance would provide a single voice on appropriate sub-regional and broader Pacific regional issues. One of the stated aims of the forum was to collaborate on issues related to US association. The FSM and RMI at the time were renegotiating their respective Compacts of Free Association with the US, and Palau had a vested interest in monitoring the outcomes as a precedent for their future renegotiations. The MPS has been an annual, sometimes biannual, meeting since then, and the acronym MPS now more generally refers to the political entity, rather than to the meeting itself.

In the early days of MPS, invitations had also been extended to Nauru and Kiribati, and in 2009 a formal joint invitation was extended in the form of a resolution that made a statement of 'Micronesian Solidarity' (MPS 2009). The three northern Micronesian presidents acknowledged the significance

3 There is also an FSM-only sub-regional entity called the FSM State and National Leadership Conference (SNLC), comprised of the FSM president and vice president, four FSM state governors and heads of legislatures - speakers from Pohnpei, Kosrae, Yap and Chuuk, plus the President of the Chuuk State Senate. 
of consolidating Micronesian support in order to strengthen their position in broader Pacific regional settings, in international settings, and with development partners (MPS 2009). To date, however, Kiribati and Nauru have not joined MPS and are not likely to join anytime soon. The reasons for this are the same as those underlying northern Micronesia's sense of detachment from the rest of the Pacific - their different colonial history and difference in primary development partners, combined with geographical distance compounded by transportation limitations, which create differences in priorities during discussion.

High-priority regional and sub-regional issues have generally dominated the MPS agenda. Those issues may be, but are not necessarily always, centred on relations with the US. The respective foreign affairs office in each of the nations ${ }^{4}$ is typically charged with servicing the meetings - scheduling, drafting and compiling the agenda, background and briefing documents, taking of minutes, and finalising outcome documents - with the host nation customarily tasked with on-the-ground planning and logistical arrangements. Many of the issues seem to be permanently ingrained in the agenda (for example, immigration, climate change, and security). Others may emerge as needed for some type of action, then die out either over time or once completed to the satisfaction of the leaders. Examples of short-lived action items at the MPS include the FSM's bid to host the Western and Central Pacific Fisheries Commission ('Tuna Commission'), extension of the University of the South Pacific campus in the RMI, and US appropriation-related items such as prior service, US postal services, and other issues that may or may not be referred from the other sub-regional body, MCES.

\section{Micronesia Chief Executives' Summit}

In 2003, the chief executives of four western Micronesia island governments (the Republic of Palau, the US Territory of Guam, CNMI, and the State of Yap within the FSM) formed a unified sub-regional multilateral body for cooperative governance known as the Western Micronesia Chief Executives' Summit (WMCES). Similar to the MPS, this summit was created in order to initiate and advance sub-regional issues among leaders in western Micronesia, the key difference being that the WMCES membership includes non-sovereign states (Guam and the CNMI). While the meeting itself was the product of separate informal bilateral discussions between Palau's President Tommy Remengesau Jr and then Governors Felix P. Camacho of Guam, Benigno R. Fitial of the CNMI, and Robert Ruecho of Yap, it was Governor Camacho who pushed for the entity's creation after Palau, the FSM and RMI refused access to the MPS for nonsovereign entities. However, the credit for convening the first meeting belongs 
to President Remengesau, who, in true Micronesian brotherly solidarity, invited Governors Camacho and Fitial as leaders of non-sovereign entities to Palau to meet separately on the margins of the third MPS. Robert Ruecho, the Governor of Yap (another non-sovereign entity), was also invited at the last minute. So within less than two years after the MPS was created, the separate WMCES was initiated, both as a response to the MPS rejection of non-sovereign state membership and based on several key attributes shared by the four entities: geographical proximity in western Micronesia (hence the name of the subregional body), cultural affiliations, and historical connections that date back to pre-foreign contact days. Since the first meeting was called by President Remengesau in 2003, the WMCES has typically met twice a year. As with the first meeting, held in Palau in 2003, WMCES meetings have usually been held in tandem with the MPS to minimise logistical problems and scheduling conflicts, and to save on costs.

In March 2007, CNMI hosted the seventh WMCES summit in Saipan. Then Governor Benigno Fitial summed up the sentiments of chief executives with regard to the importance of the meetings:

This summit is successful because it facilitates information sharing on so many levels: from the chief executive level to the staff level and from the public sector to the private sector and vice versa. We have vertical and lateral information exchanges, within each government as well as between the governments and the private business sectors ... by working together as sub-regional governments and by partnering up with private industry, we put ourselves in a far better position to collectively address these regional challenges (Donato 2007).

That particular summit would have been newly elected Yap Governor Sebastian Anefal's first meeting. However, his background as FSM Secretary of Foreign Affairs probably influenced his decision to seek endorsement from the FSM national government prior to sitting in on a WMCES meeting. Ensuing discussions between Governor Anefal and President Mori in early 2007 solidified the FSM's subsequent move to join the WMCES, further paving the way for other FSM states to become members.

In 2007, after two presidencies and four years of formal and informal invitations, the FSM national government, through then President Emanuel Mori, joined the WMCES. At the next meeting in Palau in 2008, RMI, Kosrae, and Pohnpei also joined, and the 'Western' portion of the name was dropped, becoming the MCES. The subsequent meeting in Pohnpei, co-hosted by FSM President Emanuel Mori and Pohnpei Governor John Ehsa, seated Chuuk's then Governor Johnson Elimo as the final member. 
There have been informal, and rather unconvincing, discussions of further extending membership to American Samoa. While American Samoa would culturally be better suited to join the PLG, the territory's close affiliation with the US makes membership in the MCES more enticing, given the US relationsdominated agenda, but more so, because of their non-sovereign status similar to that of fellow US territories, Guam and the CNMI.

The issues discussed at the MCES, while similar to the MPS, are approached quite differently given that the entity comprises sovereign and non-sovereign states. For example, it would be pointless to hold in-depth trade discussions at the MCES (as the US controls areas such as customs and immigration for Guam). Similarly, it is not unknown for Guam and CNMI to bring along a Washingtonbased US fisheries official to an MCES meeting. This would be regarded as a diplomatic blunder, not to mention highly discourteous, to any of the three sovereign Micronesian entities were it to occur in an MPS meeting.

There are currently nine committees within the MCES, each with its own structure, oversight and management: Regional Workforce Development Council, Micronesia Regional Invasive Species Council, Micronesia Challenge, Renewable Energy Committee, Pacific Island Regional Recycling Initiative Committee, Regional Transportation Committee, Regional Tourism Council, Regional Health Committee, and Communications Committee. Some committees are funded by governments themselves, while others partner with NGOs or bilateral donors, depending on the issue. The committees meet outside of the MCES, typically prior to the final preparatory or pre-summit meetings, to finalise what is to be put before chief executives at the plenary. Full-length presentations are requested during pre-summit meetings and are further filtered for plenary meetings. The high-priority issues highlight accomplishments, challenges and recommendations. Unlike the MPS, the MCES has a more structured secretariat, the Center for Micronesian Sustainable Futures.

\section{Sub-Regional Achievements}

There are several success stories of activities that would not have been possible without the Micronesian sub-regional dimension either forefronting or advancing the issues. While these are examples of Micronesian solidarity on issues of great importance to the region, not all stories are as successful. In fact, despite the terms that established the sub-regional bodies to better align members, it is not uncommon for differences within the sub-region to sometimes surface, as in the case of RMI offering open immigration and customs, 
while the FSM and Republic of Palau have consistently and contentiously failed to reciprocate. Some examples of sub-regional successes and failures are outlined below.

\section{Climate Change}

The issue that stands out for Micronesia is that of climate change. The significance of this critical issue is reverberated at every opportunity, in virtually every leadership statement. Just as important as the issue of climate change, and in many cases more important, is the face or voice that represents it.

Palau's President H. E. Tommy Remengesau Jr has long been a strong advocate for the environment. He has won numerous environmental awards, and was featured as one of Time magazine's Heroes of the Environment for his Micronesia Challenge initiative (Shuster 2009). He was also the co-winner of the 2014 Laureate Policy Leadership award. After serving the constitutional limit of two consecutive terms in office, Remengesau shifted to parliament after winning a seat in the 2008 Palau general election. This meant he could no longer be the face of conservation efforts in Micronesia, which was considered a setback by the environmental community. Environmentalists and conservationists in the sub-region clamoured to find a voice that could take over, ending up with FSM's then President Manny Mori, who had just under a year as chief executive under his belt.

In 2008, The Nature Conservancy (TNC), a worldwide environmental nongovernment organisation with a chapter in the FSM, tried to get President Mori more interested in environmental issues by inviting him to head an FSM delegation to a convention on biological diversity in Rome. ${ }^{5}$ President Mori gave a resounding speech at the Convention on Biological Diversity. However, if there was any success associated with the trip, it ended there. As a staunch Catholic, Mori made it a priority to visit the Pope while in Rome, which immensely detracted from the primary purpose of the trip, much to the dismay of his TNC trip sponsors. While many of his subsequent speeches included issues of climate change and its importance in the sub-region, President Mori never quite captured the essence of the matter in a way that conveyed its fundamental significance. Suffice to say, environmentalists soon found that it would not be easy to live up to Remengesau's legacy, let alone simply have someone else pick up where he left off.

5 Convention on Biological Diversity Second Meeting of the Ad Hoc Open-Ended Workshop on Protected Areas. 
In November 2012, Tommy Remengesau Jr again won the Palau presidential election, sparking renewed fervour in the Micronesian environmental community and re-igniting the flame that had gradually dimmed since his temporary departure from the political limelight: 'Palau may be small, but with President Remengesau at the helm, it has a big voice' (UNEP 2015). Barely a year after the Liberal-National Coalition took power in Australia, with Prime Minister Tony Abbott announcing that climate change was not a priority for the country (Phillips 2014), Remengesau sent waves of encouragement around the Pacific with his Oceans Declaration during Palau's hosting of the 45th Pacific Islands Forum. The Oceans Declaration calls on the international community to commit to genuine partnerships to protect and manage the region's marine resources sustainably for future generations, culminating in the advocacy of a stand-alone Oceans Sustainable Development Goal. The declaration did not originate in the sub-regional bodies, however, Palau has gone on record in the MPS promoting the initiative and seeking full support from its northern Micronesian neighbours (MPS 2014).

\section{The Micronesia Challenge}

Micronesian leaders have jointly committed to the Micronesia Challenge, an initiative to effectively conserve at least 30 per cent of the near-shore and 20 per cent of terrestrial resources across Micronesia by 2020. Leaders have agreed to further advocate and promote the Micronesia Challenge at regional and international meetings, and the need to review the various work programmes (national and regional), for implementation with a view to integrate and streamline functions.

Every conservation activity in Micronesia's five jurisdictions is now linked to the Micronesia Challenge, including national plans, government strategic action plans and NGO plans. The Micronesia Challenge has also spawned several other regional environmentally related challenges around the world, such the Caribbean Challenge Initiative and the Coral Triangle Challenge.

\section{Micronesian Conservation Trust}

The environment and conservation fields have garnered worldwide financial support for adaptation and mitigation efforts. The Micronesian sub-region has established a financial mechanism for the Micronesian Challenge and other conservation efforts. The Micronesian Conservation Trust (MCT) is headquartered in Pohnpei, capital of the FSM, with an objective to build an endowment to provide sustainable financial support for conservation and natural 
resource management across Micronesia. MCT was chosen by the UN Office of Project Services to host the Micronesia Global Environment Facility and Pacific Environment Fund Small Grants Programme. In April 2015, MCT became the first national implementing entity accredited by the Adaptation Fund, allowing it to now apply for projects up to US\$1 million to support climate adaptation work in Micronesia.

\section{Rock Island Airlines}

There had been talk of Palau establishing a sub-regional airline for several years and in September 2002 that dream finally became a reality. Start-up costs were estimated at US\$5 million, contributed by both private and public donors, including the FSM (US\$1 million from Yap, US\$500,000 from the FSM national government) and Japan (US\$1 million). Operations started in August 2004 under an Air New Zealand air operators' certificate, with experienced pilots from Australia and New Zealand, and a leased 128-seat Boeing 737-33A airplane from a Swedish company. Lease costs for the aircraft were extremely low, since the company was established soon after $9 / 11$ and the SARS epidemic.

Nevertheless, operations were suspended in December 2004, after only four months, due to high costs and under-performing sales. The under-performing sales were very discouraging because most air travellers in the region preferred to travel with the sub-region's then principal airline, Continental, on account of receiving frequent flyer benefits.

If anything beneficial resulted from the Rock Island Air debacle, it was that it realised some untapped potential and prompted Continental (now United Airlines) and other airlines to increase services to Palau. As of 2013, Palau was seeing over 40 flights a week from United and other airline carriers, which has contributed significantly to tourism in the country.

\section{Sub-Regional Opportunities}

In spite of the many challenges for the sub-region, there are also many opportunities. From trade and diplomatic representation to international and regional programme access, the prospects for further Micronesian subregionalism are immeasurable. To harness this immense potential, however, will require leadership towards a common identity for the sub-region. 
During the seventh MPS in 2007, leaders directed ministers and staff to look into the possibilities of establishing a Micronesian trading bloc. After several years of negotiations, the Micronesian Trade Committee Treaty was signed in September 2014 in Samoa on the margins of the Small Island Developing States Conference. While the treaty signing was hailed as a big step forward, there is still a long way to go in terms of creating a Micronesian Trade and Economic Community (MTEC). The treaty allows for the committee to openly and actively pursue financial and other resources in order to further pursue steps toward the MTEC. The following steps have been proposed: phase one - setting the rules, institutions and infrastructure for preferential trade and investment; phase two - towards free trade and investment; phase three - harmonisation of trade and investment policies towards a customs union; phase four - realisation of a common market leading to an economic union.

There are also opportunities that have been formally or informally raised, such as Micronesian joint diplomatic representation in Europe (as a result of increasing European Union presence in the region) and tapping into the potential of high numbers of retiring Micronesian US military service members. Other possible opportunities that are more focused on the South Pacific include membership in the new Pacific Islands Development Forum and the long established University of the South Pacific. There is also a joint Micronesian effort to gain improved access to international and regional programmes, such as the United Nations Development Programme Pacific Centre, Pacific Islands Forum Secretariat, Secretariat of the Pacific Community, ${ }^{6}$ other CROP Agencies, and the Development Cooperation Scheme between Fiji and the Pacific Island countries, in which only RMI, Nauru and Kiribati have thus far participated since its inception in 2013.

It can be said that personalities in northern Micronesian sub-regionalism are just as important as the issues themselves. One critical sub-regional opportunity that is currently unfolding is that of the new FSM leadership. The FSM congress has recently installed President Peter Christian, former chair of the FSM's compact renegotiation team and a career politician known for his nononsense attitude with US policy-makers. In 2011, Senator Christian introduced a resolution in the 17th FSM congress to prematurely terminate the Amended Compact of Free Association with the US. FSM Congress Resolution Number 17-61 submitted, among many other allegations, that the US had abused its power under the Amended Compact with the FSM and made decisions that are contrary to the interests of the country. At a time when all three northern Micronesian nations are fighting an uphill battle of prioritising development interests both independently and under their respective Compacts of Free

6 Despite FSM's hosting of a regional SPC office in Pohnpei. 
Association, a categorical yet guarded cynicism is an indispensable quality to have in current leaders. President Christian, a veteran statesmen, may be just the right person needed to bring those long overdue qualities to the forefront of the sub-regional agenda.

\section{Conclusion}

Sub-regionalism has established a secure foundation in northern Micronesia. However, two questions remain to be answered: who is sub-regionalism for, and what characterises Micronesian identity? Perhaps a coordinated response can answer both questions and, given the many opportunities that exist, these questions will be answered sooner than one may think. In the meantime, while regional experience, knowledge and information-sharing are the wind needed in the sails of Micronesian sub-regionalism, leaders of the FSM, RMI, and Palau, as well as Guam and the CNMI, must recognise that the 'Micronesian Way' of looking north is coming to an end. It is time to look south, where true solidarity rests with fellow Pacific Islands.

\section{References}

Donato, A.E., 2007, 'Micronesian Summit Ends Successfully', Saipan Tribune, 22 March. Available at: pidp.eastwestcenter.org/pireport/2007/March/03-2301.htm.

Federated States of Micronesia (FSM) Information Services, 2001, 'Historic Meeting of Heads of Government', press release, May, FSM Office of the President. Available at: www.fsmgov.org/press/pr05000c.htm.

Micronesian Presidents' Summit (MPS), 2009, 'Eneko Communique: Ninth Micronesian Presidents Summit', Majuro, Republic of the Marshall Islands, 16-17 July, FSM Information Services, Public Information Office, FSM Office of the President, Palikir, Pohnpei.

Micronesian Presidents Summit, 2014, 'Pasa Island Communique: 14th Micronesian Presidents Summit', Pohnpei, Federated States of Micronesia, 17-18 July, FSM Information Services, Public Information Office, FSM Office of the President. Palikir, Pohnpei.

Pacific Islands Forum Secretariat (PIFS), 2015, 'About Us: The Pacific Islands Forum'. Available at: www.forumsec.org/pages.cfm/about-us/. 
Phillips, A., 2014, 'Anger Mounts after Australian PM calls Climate Concerns 'clutter,' Refuses to Mention Them', thinkprogress.org, 3 April. Available at: thinkprogress.org/climate/2014/04/03/3422480/australian-g20-climateneglect/.

Secretariat of the Pacific Community (SPC), 2011, 'About SPC: History'. Available at: www.spc.int/en/about-spc/history.html.

Shuster, D.R., 2009, 'Micronesia in Review: issues and events, 1 July 2007 to 30 June 2008: Republic of Palau', The Contemporary Pacific 21(1), pp. 136-43.

United Nations Environment Programme (UNEP), 2015, '2014 Laureate Policy Leadership (co-winner)'. Available at: www.unep.org/champions/ laureates/2014/remengesau.asp\#sthash.eX2IlBSH.NYqd5WsT.dpbs. 
This text is taken from The New Pacific Diplomacy, edited by Greg Fry and Sandra Tarte, published 2015 by ANU Press, The Australian National University, Canberra, Australia. 